\title{
ESTÁGIO CURRICULAR E AUTORIA: DIÁLOGOS PARA A FORMAÇÃO DO FUTURO PROFESSOR
}

\author{
CURRICULAR INTERNSHIP AND AUTHORSHIP: DIALOGS \\ TO THE TRAINING OF THE FUTURE TEACHER
}

\author{
ESTANCIA CURRICULAR Y AUTORÍA: DIÁLOGOS PARA \\ LA FORMACIÓN DEL FUTURO PROFESORAD
}

\author{
Filomena Elaine Paiva Assolini ${ }^{\mathrm{I}}$ \\ Andrea COELho Lastória ${ }^{\mathrm{I}}$ \\ ERICA Mancuso SCHADEN ${ }^{\text {II }}$
}

\begin{abstract}
Resumo Apresentamos resultados de pesquisa de Mestrado, concluída em 2015, quando se investigou se os graduandos do curso de Pedagogia podem assumir a posição de sujeitos-autores, durante a realização do estágio curricular. Apoiamo-nos, também, na Análise de Discurso francesa (pecheuxtiana), na teoria Sócio-Histórica do Letramento e nos estudos de Formação Inicial de Professores. Com base na análise discursiva dos recortes oriundos dos questionários realizados, compreende-se que o sujeito-estagiário, quando ocupa o lugar de "intérprete-historicizado", consegue romper os sentidos legitimados e instituídos pela escola, deslocar-se para outras formações discursivas e conhecer outras zonas de sentido, requisitos basilares para se constituir autor. Por sua vez, quando lhe é vetado inscrever-se em diferentes formações discursivas, que não as que a escola reconhece como legítimas, raramente consegue posicionar-se como intérprete-historicizado, problematizar a docência e seus desafios e ressignificar sentidos institucionalizados. Nessas condições de produção, a assunção da autoria é afetada negativamente. Defendemos que os estágios curriculares, um dos momentos destinados à formação do futuro professor, tornam-se significativos aos graduandos quando são autorizados a interpretar e a se constituírem autores de suas práticas, saberes e fazeres pedagógicos.
\end{abstract}

Palavras-chave: Estágio curricular; Análise de discurso francesa; Autoria.

I Faculdade de Filosofia, Ciências e Letras de Ribeirão Preto -Universidade de São Paulo (FFCLRP-USP), Ribeirão Preto/SP - Brasil.

II Professora do Ensino Básico Público. 
Abstract We present Master's research results completed in 2015 that investigated whether graduating on Pedagogy may take the position of subject authors, while conducting the curricular traineeship. We based ourselves also in the French Discourse Analysis (from Michel Pêcheux), the Socio-Historical theory of literacy and in the studies of Initial Teacher Education. Based on the discursive analysis of clippings arising from the questionnaires, it is understood that the subject trainee when takes the place of "interpreter historicized" can break the legitimate meanings that are established by school, dislocate to other discursive formations and meet other areas of meaning, one of the basic requirements to be author. On the other hand, when it is vetoed subscribe to different discursive formations than the school recognizes as legitimate, rarely manages to position itself as an interpreter-historicized, discuss teaching and its challenges and reframe meanings that are institutionalized. In these production conditions, the assumption of authorship is negatively affected. We advocate that the curricular traineeship, one of the moments for the formation of future teachers, become significant to graduate students when they are allowed to interpret and to constitute authors of their practices, their knowledge and their practice teaching.

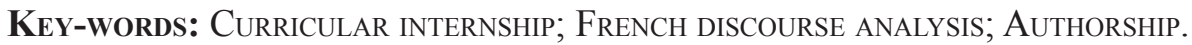

Resumen Presentamos resultados de una investigación de Máster, finalizada en 2015, que ha investigado si los estudiantes de Pedagogía desarrollaron la posición de sujetos autores durante sus estancias curriculares. Apoyándonos en el Análisis del Discurso francés (pecheuxtiano), en la teoria Sócio-Historica del Letramento y en los estudios de Formación Inicial del Profesorado. Tomando por base las secuencias discursivas, hemos constatado que el estudiante pasa a ser un "interprete-historicizado", cuando irrumpe con los sentidos institucionales cristalizados en la escuela. La liberdad de interpretación se manifestará cuando se consolide la posición docente, posiblitando así la expresión de sus alumnos. Al reves, cuando no aparece la acción de autoria el estudiante no podrá construir y fortalecer sus actitudes de autor perjudicando su formación docente. Abogamos que el practicum curricular (estancias) deben de concretizarse en momentos de autonomia de la escritura, constituyéndose así en autores ínterpretes-historicizados de sus prácticas pedagógicas.

Palabras clave: Practicum curricular; Análisis del discurso francés; Autoría.

\section{INTRODUÇÃo}

Regulamentado por leis, decretos e normativas educacionais (BRASIL, 1996, 2002, 2005, 2014), o estágio curricular encontra-se presente nos currículos brasileiros dos cursos de graduação. Nessas legislações educacionais, destaca-se a necessária articulação do estágio curricular com os demais componentes curriculares, visto ser considerado importante momento para a formação profissional, e, no caso dos cursos de licenciatura, essencial para a constituição da identidade do futuro professor.

Devido à sua relevância, com relação à sua concepção e prática, o estágio curricular encontra-se regulamentado legalmente, cuja realização deve ser atendida pela instituição superior, como a destinação de carga horária de 300 horas para a prática de estágios curriculares, os quais devem ser um elo entre a universidade e as necessidades das escolas. Ou- 
tro ponto presente nas legislações condiz com a relação entre a teoria e a prática. O estágio curricular é prática ou teoria, ou ambas? Especificamente para a graduação em Pedagogia, além do cumprimento das 300 horas de estágio curricular, deve ser realizado no âmbito da Educação Infantil e anos iniciais do Ensino Fundamental, incluindo-se outras áreas nas quais o pedagogo possa atuar, como na Educação de Jovens e Adultos (EJA), Educação Profissional, Gestão Escolar e na esfera não escolar.

Destacamos o que está disposto nas Diretrizes Curriculares Nacionais (DCN) para o curso de Pedagogia (Parecer CNE/CP n .05 , de 13 de dezembro de 2005'), a fim de responder tal questão: o estágio curricular deve se caracterizar por atividades pedagógicas, regulamentado pelo sistema de ensino, que enseja a relação entre instituições (universidade e escola) e entre docente e aluno, cabendo ao professor assumir a posição de supervisão acadêmica.

Neste trabalho, interessa-nos os dizeres a respeito da constituição de autor ao longo da realização dos estágios curriculares. Ainda com essa legislação educacional, a tarefa do docente universitário, na função de supervisão acadêmica dos estágios curriculares,

\begin{abstract}
[...] deve proporcionar ao estagiário uma reflexão contextualizada, conferindo-lhe condições para que se forme como autor de sua prática, por meio da vivência institucional sistemática, intencional, norteada pelo projeto pedagógico da instituição formadora e da unidade campo de estágio. Durante o estágio, o licenciando deverá proceder ao estudo e interpretação da realidade educacional do seu campo de estágio, desenvolver atividades relativas à docência e à gestão educacional, em espaços escolares e não-escolares, produzindo uma avaliação desta experiência e sua auto-avaliação (BRASIL, 2005, grifos do autor).
\end{abstract}

A importância dessa etapa na vida dos graduandos, descrita na própria DCN de Pedagogia, como condição para a formação autoral de práticas pedagógicas, instigou-nos a investigar como o estágio curricular tem se constituído como espaço formativo, por meio do discurso de graduandos do curso de Pedagogia, de duas diferentes universidades brasileiras, que cursavam disciplinas de estágio curricular vinculadas ao ensino da Língua Portuguesa.

Para a elaboração deste artigo, baseamo-nos na dissertação de Mestrado, defendida em 2015 e financiada pela Fundação de Amparo à Pesquisa do Estado de São Paulo (Fapesp), em que se pesquisou se os graduandos do curso de Pedagogia podem assumir a posição de sujeitos "intérpretes-historicizados" (ASSOLINI, 2014), durante a vivência nos estágios curriculares. Neste trabalho, retomamos a citada pesquisa, com o objetivo de aprofundá-la e ampliá-la.

Um de nossos propósitos relaciona-se ao conceito de "intérprete-historicizado" que tem sido desenvolvido pela professora Filomena Elaine Assolini (2013), cuja proposta se constitui como primeiro momento autoral do sujeito, já que, para que se torne autor de seus dizeres e fazeres pedagógicos, é necessário que seja autorizado a poder se expressar e lidar com o jogo interpretativo. Dessa maneira, rompe-se o discurso instituído e literal e se pro-

No período em que foi realizada a pesquisa, a Resolução 2/15, do CNE ainda não havia sido publicada. Por isso, baseamo-nos no Parecer CNE/CP nº. 05, de 13 de dezembro de 2005. 
move que o sujeito, nesse caso, o graduando, possa se arriscar a novos sentidos e a ocupar novas posições discursivas, possibilitando-lhe vivenciar diferentes experiências e romper com os saberes e fazeres pedagógicos tradicionais.

Além desse conceito, constituem-se como base teórica e metodológica do presente artigo os pressupostos da Análise de Discurso francesa, propostos pelo filósofo francês Michel Pêcheux, bem como da teoria Sócio-Histórica do Letramento, principalmente os estudos sobre autoria, e os trabalhos na área da Formação Inicial de Professores.

Com relação aos dizeres dos graduandos, originam-se de questionários com cinco questões semiestruturadas acerca da temática do estágio curricular, sendo que alguns deles foram selecionados para subsidiar as análises discursivas, ilustradas por sequências discursivas, conforme propõe a matriz francesa da Análise de Discurso (AD).

Nosso artigo está estruturado em quatro partes: na primeira, contextualizamos brevemente a proposta da Análise de Discurso francesa, desenvolvida por Pêcheux, bem como os conceitos que a alicerçam e à nossa investigação; na segunda, adentramos na temática da autoria, ao detalhar a respeito da noção de "intérprete-historicizado", elaborada por Assolini; na terceira, trazemos a discussão sobre o estágio curricular, sobretudo o debate acerca de sua identidade (se é prática e/ou teoria); na quarta, concentramo-nos na explicitação dos procedimentos metodológicos adotados e no desenvolvimento da análise discursiva, com base nos dizeres presentes em dois questionários respondidos por graduandos do curso de Pedagogia; por fim, as considerações finais, ressalvando-se que, para a Análise de Discurso francesa, os sentidos não são únicos, literais e determinantes, mas permeados por nuances de olhares e escutas, isto é, pelo ato interpretativo.

\section{ANÁliSe DE DISCURSO FRANCESA NA SUSTENTAÇão DIZERES}

A proposta teórica e metodológica à qual nos filiamos refere-se à Análise de Discurso francesa (doravante AD), desenvolvida por Michel Pêcheux, nos anos 1960. Dialogando com vários campos do conhecimento, o que the traz caráter de interdisciplinaridade, a $\mathrm{AD}$ é composta por três importantes eixos: a Psicanálise de Jacques Lacan, o materialismo histórico de Louis Althusser e a Linguística.

Sistematizada por Maldidier (2003, 2011), a AD é marcada por três fases cruciais, que impulsionaram e proporcionaram a consolidação desse campo do conhecimento. ${ }^{2}$ Da análise automática do discurso, com a promessa de se valer de uma "máquina discursiva" para o estudo discursivo, passou-se para a crítica dessa proposta, pelo próprio Pêcheux, levando a $\mathrm{AD}$ à abertura para a heterogeneidade do discurso e para os múltiplos sentidos, fruto do processo interpretativo.

Para isso, conceitos-chave sustentam a $\mathrm{AD}$, fornecendo-lhe uma identidade própria. Entre eles, destacam-se: discurso, formação discursiva, formação ideológica, condições de produção, interdiscurso, intradiscurso, ideologia, formação imaginária, memória discursi-

2 Detalhes sobre a história da Análise de Discurso francesa são explicitados por GREGOLIN (2006), MALDIDIER $(2003 ; 2011)$. 
va, esquecimentos $n^{\circ} .1$ e $n^{\circ} .2$. Alguns desses conceitos que compõem a AD francesa serão explicitados a seguir.

Comecemos pelo conceito de discurso, o qual dá nome à teoria.

Segundo propõe a $\mathrm{AD}$, o discurso não se confunde com o texto (objeto da Análise de Conteúdo), bem como não se restringe ao esquema de que se vale de um emissor, um código e um receptor, cuja mensagem seria decodificada pelo receptor exatamente como foi enviada. Para a AD não há emissor e receptor, mas, sim, sujeitos do discurso. Como aponta Orlandi (2009, p. 21), "a linguagem serve para comunicar e para não comunicar. As relações de linguagem são relações de sujeitos e de sentidos e seus efeitos são múltiplos e variados. Daí a definição de discurso: o discurso é efeito de sentidos entre locutores".

Assim, as relações entre sujeitos e sentidos consubstanciam-se a partir de condições de produção discursivas. Esse é outro conceito importante para a AD. Entende-se por condição de produção o contexto sócio-histórico, relacionado com o contexto imediato do acontecimento discursivo.

A memória discursiva dos sujeitos e as formações imaginárias são, também, elementos integrantes das condições de produção. Relacionada com a noção de antecipação, a formação imaginária compõe-se pela projeção da imagem das posições discursivas ocupadas pelos sujeitos.

Temos assim a imagem da posição sujeito locutor (quem sou eu para lhe falar assim?), mas também a posição sujeito interlocutor (quem é ele para me falar assim, ou para que eu the fale assim?), e também a do objeto do discurso (do que estou the falando, do que ele me fala?). É pois todo um jogo imaginário que preside a troca de palavras. E se fazemos intervir a antecipação, este jogo fica ainda mais complexo pois incluirá: a imagem que o locutor faz da imagem que seu interlocutor faz dele, a imagem que o interlocutor faz da imagem que ele faz do objeto do discurso e assim por diante (ORLANDI, 2009, p. 40).

Com relação à formação discursiva (FD), inicialmente foi formulada por Foucault, aparecendo na "Arqueologia do Saber" (1969) e, posteriormente, reelaborada e publicada por Pêcheux na Revista Langages, número 24. Entendida como a determinação do "[...] que pode e deve ser dito a partir de uma dada posição numa dada conjuntura" (ORLANDI, 2009, p. 43), relaciona-se estritamente com a formação ideológica (FI).

Chamaremos, então, formação discursiva aquilo que, numa formação ideológica dada, isto é, a partir de uma posição dada numa conjuntura dada, determinada pelo estado da luta de classes, determina o que pode e deve ser dito (articulado sob a forma de uma arenga, de um sermão, de um panfleto, de uma exposição, de um programa etc.) (PÊCHEUX, 1997, p. 260).

Assim, as formações discursivas estão inscritas em formações ideológicas, posto o discurso ser determinado pela ideologia, o que faz que as palavras mudem de sentido, conforme transitam pelas FDs. O sujeito se inscreve em uma FD, acreditando na literalidade, transparência e sentido único e fixo de seu discurso. 
É a ideologia que apresenta a ideia da transparência do discurso, direcionando o sujeito a acreditar na evidência do sentido. É a ideologia que fornece as evidências pelas quais "todo mundo sabe" o que é um soldado, um operário, um patrão, uma fábrica, uma greve etc., evidências que fazem com que uma palavra ou um enunciado "queiram dizer o que realmente dizem" e que mascaram, assim, sob a "transparência da linguagem", aquilo que chamaremos o caráter material do sentido das palavras e dos enunciados (PÊCHEUX, 1997, p. 160, grifos do autor).

Outro conceito essencial para AD é o interdiscurso. Originário da noção de pré-construído, elaborada por Paul Henry e Michel Pêcheux, o interdiscurso refere-se a discursos outros, já ditos, que são ressignificados na FD, em que o sujeito se inscreve. Assim, "o que é dito em outro lugar também significa nas 'nossas' palavras" (ORLANDI, 2009, p. 32).

Distinto de intertextualidade, concepção proposta por Mikhail Bakhtin, no interdiscurso sentidos são reatualizados no acontecimento discursivo (intradiscurso). Já o intertexto se caracterizaria pela relação entre textos, muitas vezes, de forma direta.

O interdiscurso é considerado o eixo vertical do discurso e o intradiscurso o eixo horizontal: "nesse sentido, pode-se bem dizer que o intradiscurso, enquanto 'fio do discurso' do sujeito, é, a rigor, um efeito do interdiscurso sobre si mesmo, uma 'interioridade' inteiramente determinada como tal 'do exterior"' (PÊCHEUX, 1997, p. 167).

Após a abordagem de alguns conceitos que embasam a $\mathrm{AD}$, passemos a outro conceito essencial que sustenta as discussões propostas neste artigo: o "intérprete-historicizado".

\section{O INTÉRPRETE-HISTORICIZADO: PERMISSÃO PARA INTERPRETAR}

A concepção de autoria e autor é tema de discussão de vários estudiosos. Michel Foucault (1996, 2009), Leda Verdiani Tfouni (1997) e Eni Orlandi (2003) são somente alguns representantes. Embora em seus trabalhos possamos notar pontos que dialogam ou divergem entre si, a presença desse assunto demonstra a importância e a atualidade em se discutir a respeito da autoria e a constituição do autor.

Na perspectiva de Foucault (1996, 2009), não são todos os discursos que apresentam autoria. Além disso, cada momento histórico e cada sociedade estabelecem quais atributos a regem. Mesmo diferenciando-se entre si, a concepção de autoria e autor tem como um de seus princípios a noção de "fundadores de discursividades".

Segundo Foucault, esse princípio determina que os sujeitos só se tornam autores quando seus discursos retomam um discurso anterior, propiciando, por aproximação ou diferenciação, o surgimento de novos discursos, por exemplo, uma proposta teórica. Nesse ensejo, o discurso, para ser considerado regido pela autoria, deve também possuir unidade, coerência e coesão. Com base no que aponta a $\mathrm{AD}$, os discursos não são transparentes e literais, mas para que a autoria se instale, é preciso que apresentem unidade, mesmo que ilusória. Compreende-se, portanto, 
[...] o autor, não entendido, é claro, como o indivíduo falante que pronunciou ou escreveu um texto, mas o autor como princípio de agrupamento do discurso, como unidade e origem de suas significações, como foco de sua coerência (FOUCAULT, 1996, p. 27-28).

Para Tfouni (1997), a autoria pode estar presente nos discursos escritos como também orais, rompendo, assim, com a Teoria da Grande Divisa que valoriza a escrita em face da fala, situação ainda muito presente no universo escolar. Ao distinguir alfabetização de letramento, reconhece que a autoria pode se inscrever no discurso de não alfabetizados, mas com alto nível de letramento. Isso, porque, embora exista a dispersão e a não transparência discursiva, se o discurso se apresentar com coesão e coerência, envolvido pelo ato interpretativo, pode-se reconhecer a posição de autor.

Dialogando com o que já foi explicitado, Orlandi (2003) discorre que a interpretação está presente em todos os momentos da vida do sujeito, por isso, posicionar-se como autor não é uma condição restrita para poucos, segundo aponta. No entanto, esclarece que o sujeito sofre instâncias de controle de sua interpretação, as quais, por deixar brechas, permitem que ele possa rompê-las.

A autoria, na perspectiva de Orlandi, é essencial ao discurso, pois é ela que fornece a unidade do dizer, ou seja, uma tentativa de se estabelecer coesão e coerência no discurso: "se o sujeito é opaco e o discurso não é transparente, no entanto o texto deve ser coerente, não-contraditório e seu autor deve ser visível, colocando-se na origem de seu dizer" (ORLANDI, 2003, p. 75-76).

Além dessas concepções, outra tem sido desenvolvida, a fim de colaborar para essa temática. No caso, destacamos o conceito de "intérprete-historicizado", elaborado por Assolini, que tem se dedicado, ao longo dos anos, a aprofundá-lo e a desenvolvê-lo.

Para discorrer sobre o processo de construção desse conceito, valemo-nos de um artigo científico publicado pela autora, em 2012. Esse recorte é um procedimento metodológico que adotamos para apresentar brevemente esse caminho de elaboração conceitual, visto que esse conceito tem sido exibido na maioria dos trabalhos da citada autora.

Selecionamos o artigo intitulado "Docentes do Ensino Superior e suas relações e práticas de leitura: implicações para a (des)construção de sua(s) identidade(s)" (2012), no qual a pesquisadora propôs-se a investigar quais são as relações dos professores de licenciatura com a leitura, ao longo de suas formações em cursos de graduação e pós-graduação, e se essa relação reverbera em seus saberes e fazeres profissionais.

Neste artigo, apoia-se na discussão pecheuxtiana sobre duas posições-sujeito (escrevente e intérprete), a fim de sustentar o desenvolvimento do conceito de "intérprete-historicizado". Para isso, destaca que a posição de sujeito "escrevente" relaciona-se ao sujeito que mantém os efeitos de literalidade do discurso, ou seja, que realiza leituras e interpreta, filiando-se às formações discursivas, marcadas por sentidos legitimados socialmente e naturalizados pelas formações ideológicas às quais essas formações discursivas se remetem. Em contraponto, está a posição de sujeito "intérprete", posição a partir da qual o sujeito pode rever suas formas de leitura e de interpretar, abrindo-se para novos sentidos e se afastando da literalidade dos sentidos instituídos. 
Esse processo, segundo a autora, aproxima-se do après-coup (posterioridade), proposto por Freud (2006) e desenvolvido por Lacan (1986). Nessa situação, quando pode transitar de uma formação discursiva a outra, o sujeito atribui outros sentidos a determinadas experiências vividas, ressignificando-as, algo bem próximo do "intérprete-historicizado", o qual apresentaremos a seguir.

O conceito de "intérprete-historicizado" dialoga com as concepções de autoria, desenvolvidas pelos autores já citados, enriquecendo-as com a questão da autorização para a interpretação.

Salientamos que ocupar a posição intérprete-historicizado é condição fundamental para que o sujeito se constitua autor de seu próprio dizer. As pesquisas da autora assinalam que sujeitos não autorizados a interpretar, no contexto escolar, raramente produzem textos caracterizados pela autoria; não se atrevem a se deslocarem da paráfrase e circularem por outras zonas de sentido, que não as que vigoram na escola, entendida, aqui, como Aparelho Ideológico de Estado (ALTHUSSER, 1985). Assim, é essencial que ao sujeito sejam possibilitadas oportunidades e espaços para poder lidar com outros sentidos, que não sejam somente os instituídos, predeterminados. Que nesse processo possa emergir sua subjetividade e discursos outros (interdiscurso), possibilitando o exercício criativo. Dessa forma, para ser autor, é imprescindível ser antes "intérprete-historicizado", ou seja, quem "[...] está autorizado a falar, a produzir outras leituras, recontar histórias, a partir de sua memória discursiva" (ASSOLINI, 2010, p. 29).

\section{Estágio: LUGAR dA(s) PRÁTICA(s) E TEORIA(s)}

Diversas são as propostas teóricas que abordam o estágio curricular, componente dos cursos de licenciatura. A maioria dessas concepções trata da questão do lugar dado à prática e à teoria na formação inicial de professores. Pedagogia das Competências, Pedagogia Construtivista, Pedagogia Reflexiva, Pedagogia Crítica, entre outras vertentes, a problemática da teoria e prática é abordada, no entanto, sob sentidos distintos, às vezes, contrastantes.

Segundo Duarte (2010), as propostas pedagógicas da Pedagogia Reflexiva, Pedagogia Multiculturalista, Pedagogia de Projetos e Pedagogia das Competências compõem o que o autor chama de Pedagogias Contemporâneas, que versam sobre a temática do "aprender a aprender". Criticando essas propostas, aponta que as Pedagogias Contemporâneas, embora possuindo diferenças entre si, assemelham-se por apresentarem visão fragmentária da realidade. Dessa forma, enfocam determinada questão, sem abranger sua totalidade. Um dos focos mais recorrentes é o cotidiano escolar.

Sem rejeitar a importância de se analisar o cotidiano escolar, o autor defende que esse elemento não deve ser o ponto central das propostas curriculares, devendo ser considerado como mais um eixo na elaboração dos currículos. Qual a razão para isso?

Duarte (2010, p. 36) esclarece que a preponderância do cotidiano, com ênfase na experiência vivida pelo sujeito, atrela-se a uma ótica que prima pela defesa da aplicação prática dos conhecimentos, ou seja, "[...] soma-se a esse utilitarismo o princípio epistemológico 
pragmatista de que o conhecimento tem valor quando pode ser empregado para a resolução de problemas da prática cotidiana".

A crítica do autor à abordagem do cotidiano do aluno no currículo escolar relaciona-se à sobrevalorização dos conhecimentos pontuais, tácitos, informais, não sistematizados e à ausência dos conhecimentos científicos e históricos, desenvolvidos pela humanidade, ao longo do tempo.

Nesse mesmo viés, Pimenta (2006, p. 43) tece críticas às Pedagogias Contemporâneas e propõe que essas propostas sejam revisitadas e ampliadas. Segundo a autora, essas Pedagogias caracterizam-se pelo "[...] individualismo da reflexão, a ausência de critérios externos potenciadores de uma reflexão crítica, a excessiva (e mesmo exclusiva) ênfase nas práticas, a inviabilidade da investigação nos espaços escolares e a restrição desta nesse contexto".

Apoiando-se na Pedagogia Crítica, desenvolvida por Giroux (1997), a autora pontua que as Pedagogias Contemporâneas deveriam se ampliar para tornar a proposta da reflexão da prática pedagógica e da ênfase no cotidiano escolar uma realização coletiva, crítica, que dialogue com outros projetos educativos, garantindo a finalidade da transformação social e política.

A constituição do profissional crítico-reflexivo envolve a reflexão intencional, problematizada, por meio da prática e da teoria. Nesse ensejo, é importante destacar que, conforme explicita Charlot (apud PIMENTA, 2006), a prática pedagógica apresenta uma teoria subjacente. A ação pedagógica, tanto na escola como na universidade, é composta por práticas e teorias. Dessa maneira, é equivocado pensar que somente há prática no contexto escolar do ensino básico, por exemplo, e teoria no universitário.

\begin{abstract}
Assim, acho que a questão é a troca entre dois tipos de teoria: uma enraizada nas práticas, nas situações, e outra enraizada no desenvolvimento de uma ciência ou de várias ciências, como a Sociologia, a Psicologia ou as Ciências da Educação. Portanto, não se trata de diálogo entre uma prática e uma teoria. Falar de diálogo entre teoria e prática é abrir duas possibilidades de teorismo ideológico: o teorismo do pesquisador que está dizendo "Eu sei, eu conheço a verdade, tenho uma prova" e o teorismo da prática, o teorismo do professor que diz "Eu sei porque tenho a minha experiência em sala de aula". E, para sair do teorismo, temos que organizar esse diálogo entre os dois tipos de teoria (CHARLOT apud PIMENTA, 2006, p. 95, grifos do autor).
\end{abstract}

Em meio a esses dois universos está o estagiário, percorrendo "a ponte" que une a universidade e a escola. É ele o interlocutor da teoria e prática aprendidas ao longo do curso de graduação e a teoria e prática vivenciadas durante a experiência do estágio curricular. Nesse trajeto, simbolizado pela ponte (LIMA, 2008), o estagiário enfrenta percalços, dilemas, pois, muitas vezes, esses dois importantes locus de formação pedagógica não dialogam entre si. Cabe aos educadores, tanto na universidade como na escola, contribuírem para a formação consistente como futuro professor, que, desde sempre, deve aprender a lidar com as "pedras" que encontra em seu caminho, posto que elas sempre existirão, como nos ensina o poeta Carlos Drummond de Andrade. 
Dessa forma, pode ficar despercebida uma questão fundamental, que está na base de muitos dos nossos descontentamentos e conflitos no decorrer do Estágio que é o movimento de aproximação de duas instituições de ensino, cada uma trazendo valores, objetivos imediatos, cultura e relações de poder diferentes, com o objetivo de realizarem um trabalho comum: a formação de professores. No meio destes dois campos de força está o estagiário, preocupado em cumprir os requisitos acadêmicos propostos pelo professor - orientador da disciplina e transitar de maneira satisfatória pela escola na busca de aprendizagens sobre a profissão (LIMA, 2008, p. 198).

O estágio curricular não é somente prática nem somente teoria, mas envolve a prática e a teoria da universidade e a prática e teoria da escola. Por isso, constitui-se em momento formativo importante, pois representa, para muitos graduandos, o primeiro contato com o cotidiano escolar, na posição intermediária e fluida de estagiário, mas já distinta da posição de aluno que esse sujeito ocupa na universidade.

Assim, o estágio curricular deve ser um momento cuidado pela universidade e pela escola, para que a experiência vivida pelo estagiário seja prazerosa, desafiadora e condizente com os requisitos para a formação do futuro professor.

\section{Procedimento metodológico}

O procedimento metodológico adotado neste artigo envolveu análise de dois questionários, de um total de 31 questionários, compostos por cinco questões semiestruturadas, respondidos por graduandos do curso de Pedagogia de duas universidades públicas brasileiras, durante as disciplinas que tratavam especificamente do estágio curricular para $\mathrm{o}$ Ensino Fundamental, com ênfase na abordagem do ensino da Língua Portuguesa.

Selecionamos, para este trabalho, alguns recortes e, a partir deles, algumas sequências discursivas provenientes dos questionários, a fim de analisarmos e debatermos a respeito da importância do graduando realizar estágios curriculares que lhe permitam assumir-se como "intérprete-historicizado", situação primeira da autoria.

Com base na proposta teórico-metodológica da $\mathrm{AD}$, destacamos que a análise discursiva não se restringe a um procedimento metodológico determinado. Para a $\mathrm{AD}$, “[...] a análise precede, em sua constituição, a própria teoria” (MALDIDIER, 2003, p. 25). É ao longo do processo interpretativo do analista de discurso que a análise discursiva se processa, exigindo um ir e vir ininterrupto entre teoria, consulta ao corpus e análise.

Além da questão da teoria e do método estarem imbricados no momento analítico, cabe ao analista do discurso investigar sinais, indícios e pistas (GINZBURG, 1989), como um detetive realiza em uma cena de crime. A busca pelo pormenor revela que o discurso, segundo a $\mathrm{AD}$, não se compõe pela literalidade, transparência ou obviedade. Pelo ato interpretativo, os sentidos podem ser desvelados, através do olhar e escuta atenta para o que não se apresenta em primeira instância. 


\section{ANÁlise disCURSIVA: NOSSOS GESTOS INTERPRETATIVOS}

A seguir, apresentamos as análises discursivas realizadas, por meio de recortes oriundos de dois questionários, respondidos por graduandos do curso de Pedagogia, sobre a vivência no estágio curricular.

\section{POSIÇÃO-ALUNO A}

2. Quais atividades desenvolvidas durante o estágio curricular, para o ensino fundamental, na área da Língua Portuguesa que você mais gostou de executar? Quais os alunos mais gostaram de participar?

Não executei nenhuma atividade durante o estágio.

3. Como você imaginava o momento do estágio curricular antes de vivenciá-lo? Foi parecido ou não com a sua experiência durante o estágio?

Imaginava que poderia auxiliar a professora sempre, no entanto, não foi o que aconteceu comigo, pois não tive espaço para efetuar.

4. Você acredita que o momento do estágio curricular seja importante para a sua futura atuação como professor(a)?

Com certeza, pois é o momento que mais aproxima os estudantes da pedagogia com a realidade da profissão.

Com base nos preceitos da $\mathrm{AD}$, um questionário não se restringe somente à sua função como documento, texto. Para a AD, um questionário é entendido como um discurso, dotado de sentidos sócio-históricos. Assim, indícios, pistas e marcas linguístico-discursivas são elementos fundamentais na investigação do analista de discurso que, ao evidenciá-los, pode, por meio do ato interpretativo, refletir como o sujeito posiciona-se como estagiário, ao longo de suas vivências no estágio curricular. Destacamos que essas experiências podem ser distintas, bem como as condições de produção das salas de aula estagiadas.

Iniciemos esta análise destacando a sequência discursiva: Não executei nenhuma atividade.

Refletindo sobre a (im)possibilidade de os graduandos do curso de Pedagogia posicionarem-se como sujeitos "intérpretes-historicizados" (ASSOLINI, 2014), a posição-aluno A afirma que, durante a experiência de estágio curricular, não realizou atividades com os alunos.

A dupla negativa (não... nenhuma), segundo os gramáticos, poderia resultar em seu oposto, uma afirmação (executei). Por isso, pela regra gramatical deveria se dizer, a fim de ser considerado "correto": Não executei atividade alguma.

Posto ser uma dupla negativa, possibilitando a leitura como uma afirmação, dizeres outros da posição-aluno A pontuam que sua vivência durante o estágio curricular foi interditada com um não. Ao recorrer ao "não" (advérbio de negação), seguido de "nenhuma" (pronome indefinido), a posição-aluno A reafirma a interdição e a impossibilidade de experienciar esse momento formativo, explicando o porquê: não tive espaço para efetuar. A interdição a que o estagiário está envolto pode ser compreendida pelos dizeres de Orlandi: 
[...] a situação típica da censura traduz exatamente essa asfixia: ela é a interdição manifesta da circulação do sujeito, pela decisão de um poder de palavra fortemente regulado. No autoritarismo, não há reversibilidade possível no discurso, isto é, o sujeito não pode ocupar diferentes posições: ele só pode ocupar o "lugar" que lhe é destinado, para produzir os sentidos que não lhe são proibidos. A censura afeta, de imediato, a identidade do sujeito (ORLANDI, 2007, p. 79).

A censura, tal como a definimos, é a interdição da inscrição do sujeito em formações discursivas determinadas, isto é, proíbem-se certos sentidos porque se impede o sujeito de ocupar certos lugares, certas posições. [...] Desse modo, impede-se que o sujeito, na relação com o dizível, identifique-se com certas regiões do dizer pelas quais ele se representa como (socialmente) responsável, como autor (ORLANDI, 2007, p. 104).

Diante disso, a angústia permeia seus dizeres, marcando esse discurso pela tristeza e contrariedade, em face da impossibilidade de realizar atividade pedagógica com os alunos. Essa experiência confronta-se com o que esperava ser a vivência no estágio curricular, com base em suas concepções, seu imaginário (formação imaginária) de como se realizaria esse momento: Imaginava que poderia auxiliar a professora sempre.

Para esse sujeito, o estágio curricular seria um momento de vivenciar a prática pedagógica, atuando e auxiliando a professora, e com isso aprendendo com ela. Nesse sentido, insere-se na formação discursiva (FD) que concebe o estagiário como sujeito que auxilia, ajuda, apoia o professor e que durante o estágio curricular irá aprender, trabalhar junto, "co-laborar".

Como explicita Pêcheux, a formação discursiva (FD) sempre remete à determinada formação ideológica (FI), estabelecendo sentidos que mudam conforme migram de uma FD para outra. A filiação do sujeito a uma ou outra formação discursiva não é "por acaso", pode-se assim dizer. Nessa linha de raciocínio é pertinente destacar que

[...] o sentido de uma palavra, de uma expressão, de uma proposição etc. não existe "em si mesmo" (isto é, em sua relação transparente com a literalidade do significante), mas, ao contrário, é determinado pelas posições ideológicas que estão em jogo no processo sócio-histórico no qual as palavras, expressões e proposições são produzidas (isto é, reproduzidas). Poderíamos resumir essa tese dizendo: as palavras, expressões, proposições etc., mudam de sentido segundo as posições sustentadas por aqueles que as empregam, o que quer dizer que elas adquirem seu sentido em referência a essas posições, isto é, em referência às formações ideológicas (no sentido definido mais acima) nas quais essas posições se inscrevem (PÊCHEUX, 1997, p. 260, grifos do autor).

No jogo entre as FDs, pelas margens finas e permeáveis, a posição-aluno desliza, em um movimento que permeia o inconsciente do sujeito. Dessa forma, filia-se a FDs, com as quais concorda, afastando-se de determinadas FDs, visto se identificar com certos sentidos atribuídos à sua prática, ressaltando-se que essa identificação não ocorre de forma clara e precisa. Esse trânsito envolve as formações ideológicas (FIs), às quais as FDs se vinculam, que permitem ou interditam sentidos ao discurso. 
[...] as palavras constituem seu sentido a partir da FD em que o sujeito se insere. O que define a FD é sua relação com a formação ideológica (FI), determinando o que pode ou não ser dito, a partir de uma conjuntura dada, uma vez que o sentido das palavras migra ao passar de uma FD para outra (ECKERT-HOFF, 2002, p. 30).

Retomando os dizeres da posição-aluno A, ao não ter espaço e oportunidade para atuar na posição de estagiário, foi determinado ao graduando se inscrever em uma FD com a qual não se identifica. Distante de seu imaginário a respeito do estágio curricular, posto valorizá-lo positivamente como o momento que mais aproxima os estudantes da pedagogia com a realidade da profissão, a experiência relatada contrapõe-se ao esperado.

Por conceber ser o momento que "mais" aproxima os estudantes da realidade da profissão docente, demonstrou em seus dizeres decepção e tristeza por não ter podido realizar "nenhuma" atividade durante o estágio curricular, sobretudo, no auxílio à professora (Imaginava que poderia auxiliar a professora sempre), considerado, pelo sujeito, condição intrínseca à proposta da atuação no estágio curricular.

Com base no relato da posição-aluno A, defendemos a importância de oportunidades para que os graduandos, na posição de estagiários, possam realizar as propostas pedagógicas, relacionadas aos requisitos que envolvem o estágio curricular. Dessa maneira, poderão se arriscar a outros sentidos, movimentar-se por diferentes formações discursivas, a fim de se constituírem como "intérpretes-historicizados" (ASSOLINI, 2014). Nessa posição, poderão entender-se como sujeitos capazes de estranhar sentidos e situações naturalizados, como, por exemplo, os que colocam o estagiário na condição de sujeito que deve observar passiva e resignadamente o que se passa na sala de aula.

Quando a posição-aluno A diz pois não tive espaço para efetuar, não foi somente sua experiência interditada, mas a possibilidade de (re)significar suas pré-noções sobre o exercício da docência, de conhecer novas propostas pedagógicas, possibilitando novos olhares e escuta mais apurada do cotidiano escolar. O auxílio pedagógico ao professor e aos alunos e a vivência da regência possibilitam ao graduando conhecer melhor o universo escolar e, nesse movimento, na posição fluida de estagiário, poder romper com sentidos já instituídos pelo discurso pedagógico tradicional.

É necessário, portanto, que os graduandos sejam autorizados a se tornarem "intérpretes-historicizados", condição primeira para se posicionarem como autores de seu pensar, dizer e fazer pedagógicos. Concordamos com Tardif (2012, p. 243), quando aponta que: "pessoalmente, não vejo como posso ser um sujeito do conhecimento se não sou, ao mesmo tempo, o autor da minha própria ação e o autor do meu próprio discurso".

A autorização nada mais é do que a liberdade para interpretar. Por isso, deve estar presente ao longo do processo formativo do graduando, na universidade e na escola. Cabe ao professor, longe de ser o detentor de saber, possibilitar que os sentidos possam circular e ecoar pelo mundo afora. Entretanto, é pertinente lembrar que, de acordo com a perspectiva discursiva, as interpretações podem ser muitas, inúmeras, mas não qualquer uma, visto que o sujeito interpreta a partir de um lugar determinado sócio-historicamente. O discurso, por sua vez, é produzido no âmbito de determinadas condições, também marcadas pelos aspectos sócio-históricos e ideológicos. 


\section{POSIÇÃO-ALUNO B}

2. Quais atividades desenvolvidas durante o estágio curricular, para o ensino fundamental, na área da Língua Portuguesa você mais gostou de executar? Quais os alunos mais gostaram de participar?

As atividades mais interessantes foram as contações de histórias que foram feitas de formas variadas. Para os alunos a parte mais interessante é quando eles fazem o registro da atividade podendo se expressar de forma livre e criativa.

5. O que você entende por estágio curricular?

Entendo como uma oportunidade de visualizar/participar na sala de aula como alguém neutro, sem ser na função de professor ou aluno. Entendo também como um lugar de reflexão e conhecimento que amplia a visão do graduando.

Inserida em uma formação discursiva (FD) distinta da posição-aluno A, pelas respostas dadas pela posição-aluno B, pudemos notar que esse sujeito pôde vivenciar o momento do estágio curricular. A permissão para experiênciá-lo possibilitou que o graduando pudesse se constituir como "intérprete-historicizado", primeira instância da autoria, já que lhe foi permitido desenvolver atividades pedagógicas na posição de estagiário.

Concedida a autorização, a posição-aluno B não demonstra surpresa diante do resultado da vivência no estágio curricular. Para esse sujeito, a experiência deveria ter sido positiva, pois seu discurso articula-se com a FD, com a qual se identifica, e que se constitui por esse sentido. Assim, a FD corresponde às suas expectativas a respeito desse momento formativo: um lugar de reflexão e conhecimento que amplia a visão do graduando.

Considerando ser o momento do estágio curricular uma oportunidade de refletir sobre a prática educativa, bem como de aprender com os saberes e fazeres pedagógicos do professor da sala de aula, esse sujeito pontua que essa experiência amplia a visão do graduando. Destaca-se, portanto, ser esse momento formativo imprescindível para a constituição do futuro professor.

Assim, ao considerar sua vivência significativa, responsabiliza-se em tornar as experiências educativas dos alunos também expressivas. Desse modo, elabora e desenvolve diversas atividades, como distintas maneiras que envolvem a contação de histórias (As atividades mais interessantes foram as contações de histórias que foram feitas de formas variadas), que incentivam os alunos a aprenderem de forma lúdica. Nesse processo, possibilita aos alunos que se posicionem como autores, sujeitos capazes de interpretar e lidar com as múltiplas possibilidades de sentidos, a polifonia: Para os alunos a parte mais interessante é quando eles fazem o registro da atividade, podendo se expressar de forma livre e criativa.

A posição-aluno B aborda outro importante ponto. Com base nas sequências discursivas destacadas, esse sujeito explicita sobre a questão da transitoriedade da posição de estagiário. Por estar na margem, no trânsito entre a universidade e a escola, a atuação como estagiário permite que navegue pelas beiras das FDs. Por serem tênues, possibilitam que o sujeito se inscreva em FDs, com as quais se identifica, ou se afaste das que não concorda, ressaltando-se que esse processo não é exclusivamente consciente. Assim, a posição assu- 
mida como estagiário é entendida como estar entre dois mundos, supostamente concebido pela neutralidade: entendo [o estágio curricular] como uma oportunidade de visualizar/ participar na sala de aula como alguém neutro, sem ser na função de professor ou aluno.

No entanto, assumir uma posição neutra não é possível. O sujeito sempre toma partido, mesmo que o faça em silêncio, como aponta Orlandi (2009). Isso, porque, estar em silêncio é significar, sendo que "[...] mais se diz, mais o silêncio se instala, mais os sentidos se tornam possíveis e mais se tem ainda a dizer" (ORLANDI, 2007, p. 69). O silêncio também se relaciona com o interdiscurso que, segundo Pêcheux (1997, p. 162), "[...] reside no fato de que 'algo fala' (ça parle) sempre 'antes, em outro lugar e independentemente', isto é, sob a dominação do complexo das formações ideológicas".

A posição-aluno B, na ilusão da literalidade de sua posição como estagiário, acredita que, por se constituir pela neutralidade, não influencie com sua presença a dinâmica na sala de aula. Além de sua presença, as atividades desenvolvidas, como permitir aos alunos que pudessem se expressar de forma livre e criativa, certamente reverberarão ao longo da trajetória escolar desses alunos, deixando marcas. Como destaca Assolini, com relação ao graduando "[...] em sua futura atuação profissional, poderá ocupar ou não a posição de um agente de mudanças e transformações, mas, inevitavelmente, sempre deixará no outro marcas de seu dizer" (ASSOLINI, 2011, p. 42).

Defendemos que sejam promovidas condições de produção para que os graduandos, assumindo a posição de estagiários, tenham liberdade para se expressarem, bem como desenvolverem projetos de intervenção e momentos de regência, a fim de que possam aprender a se posicionarem como autores de seu próprio dizer. Trata-se de uma posição imprescindível para o exercício responsável, autônomo e criativo da docência que, na contemporaneidade, não mais aceita professores que somente reproduzem o que lhe é imposto ou sugerido por órgãos oficiais de ensino. A autoria é imprescindível para a atuação pedagógica dos professores, dos alunos, assim como dos futuros professores, na posição de estagiários.

\section{CONSIDERAÇões FINAIS}

As análises discursivas apresentadas, referentes às posições-aluno selecionadas, permitem-nos visualizar duas situações, relacionadas com as experiências dos graduandos, ao longo dos estágios curriculares.

No caso da posição-aluno A, tem-se a interdição como regente da vivência no estágio curricular, a qual impossibilitou que o sujeito pudesse ocupar o lugar de estagiário, no desenvolvimento de projetos, planos de aula e momentos de regência autorais.

Ao destacar que não pode efetuar, realizar, esse sujeito-estagiário evidencia que não pode transitar para outra formação discursiva, permanecendo em meio ao discurso pedagógico tradicional. Possivelmente, foi restringido a esse sujeito alocar-se na posição de aluno, nos moldes da educação tradicional, na qual o professor fala (e tem sempre algo a dizer) e o aluno escuta, calado. 
Permanecer nessa FD promove angústia e tristeza, por acreditar que o momento do estágio curricular é um dos mais importantes para a aproximação do aluno com o cotidiano escolar, um dos locais de exercício da profissão do professor. No entanto, mesmo atrelado ao discurso escolar dominante e sendo impedido de se constituir como autor, a experiência da angústia promoveu um deslocamento, uma marca, que possivelmente ressoará e poderá ser agente de transformação de sua futura prática docente.

Com relação à posição-aluno $\mathrm{B}$, a experiência no estágio curricular marcou-se pela abertura para poder atuar como estagiário, bem como ousar a outros sentidos e a transitar por diferentes formações discursivas. Nesse caso, a vivência no estágio curricular caracterizou-se pela variedade de práticas pedagógicas proporcionadas ao ensino dos alunos, permitindo que também pudessem assumir a posição de "intérpretes-historicizados", primeiro momento da autoria.

Por conta disso, esse sujeito inscreveu-se em formações discursivas com as quais se identifica, distanciando-se do discurso pedagógico tradicional. Desse modo, sua atuação como estagiário não se restringiu à neutralidade, visto que, para a $\mathrm{AD}$, o sujeito sempre se posiciona, mesmo quando está em silêncio. Não há meios de não deixar marcas e rastros por onde se passa. São essas marcas, positivas ou não, que incidem no processo de constituição da(s) identidade(s) do sujeito.

Assim, ao se posicionar como "intérprete-historicizado", proporciona ao sujeito que seus futuros alunos também possam romper com os sentidos instituídos no universo escolar. Dessa maneira, quando ao graduando não é permitido trilhar por outras propostas pedagógicas, também lhe é vetado refletir sobre suas pré-noções a respeito do cotidiano escolar, dos fazeres e saberes pedagógicos e de transitar por outras formações discursivas. Portanto, é imprescindível que momentos formativos positivos sejam promovidos nas vivências de estágio curricular, ou seja, momentos nos quais o sujeito ocupa a posição de intérprete-historicizado, condição basilar para que se constitua como autor de seu próprio dizer.

\section{REFERÊNCIAS}

ALTHUSSER, L. Aparelhos ideológicos de estado: Nota sobre os aparelhos ideológicos de estado, 3 ed. Rio de Janeiro: Graal, 1985.

ASSOLINI, F. E. P. Professoras alfabetizadoras e suas leituras: história, memória e prática pedagógica escolar. Práxis Educacional, v. 1, p. 25-45, 2010.

. Leitura e formação inicial de professores: sentidos, memória e história a partir da perspectiva discursiva. Campinas, SP, Pro-Posições (Unicamp), v. 22, p. 33-43, 2011.

. Docentes do ensino superior e suas relações e práticas de leitura: implicações para a (des)construção de sua(s) identidade(s). In: III SIMPÓSIO NACIONAL E I SIMPÓSIO INTERNACIONAL - DISCURSO, IDENTIDADE E SOCIEDADE, 2012, Campinas, SP. Anais... Campinas, SP: Unicamp, v. 1, p. 104-104, 2012.

. Professoras Alfabetizadoras e suas relações com as tecnologias de informação e comunicação: implicações para a prática pedagógica. II CONGRESSO NACIONAL DE 
FORMAÇÃO DE PROFESSORES, XII CONGRESSO ESTADUAL PAULISTA SOBRE FORMAÇÃO DE EDUCADORES, 2014, Águas de Lindóia, SP. Anais... Águas de Lindóia, SP: Unesp, v. 1, p. 6.622-6.634, 2014.

BRASIL. Lei no. 13.005, de 25 de junho de 2014. Plano Nacional de Educação (PNE) e dá outras providências. Diário Oficial da União, Brasília, DF: 2014.

. Conselho Nacional de Educação. Parecer CNE/CP n⿳0 5, de 13 de dezembro de 2005. Diretrizes curriculares nacionais para o curso de pedagogia. Brasília, DF: 2005.

. Conselho Nacional de Educação. Resolução CNE/CP n⿳01, de 18 de fevereiro de 2002. Diretrizes curriculares nacionais para a formação de professores da educação básica em nível superior para os cursos de graduação plena em licenciatura. Brasília, DF: 2002.

. Ministério da Educação. Lei n⿳0 9.395. Lei de Diretrizes e Bases da Educação Nacional. Brasília, DF: 1996.

DUARTE, N. O debate contemporâneo das teorias pedagógicas. In: MARTINS, L. M.; DUARTE, N. (Orgs.). Formação de professores: limites contemporâneos e alternativas necessárias. São Paulo: Unesp/Cultura Acadêmica, 2010.

ECKERT-HOFF, B. M. O dizer da prática na formação do professor. Chapecó: Argos, 2002.

FOUCAULT, M. A ordem do discurso. São Paulo: Edições Loyola, 1996.

. O que é um autor? In: FOUCAULT, M. Estética: literatura e pintura, música e cinema (Ditos e escritos III). Rio de Janeiro: Forense Universitária, 2009.

FREUD, S. Uma neurose infantil e outros trabalhos. In: Edição Standart das obras completas de Sigmund Freud. Rio de Janeiro: Imago, 2006, v. IV.

GINZBURG, C. Mitos, emblemas e sinais - morfologia e história. São Paulo: Companhia das Letras, 1989.

GIROUX, H. A. Os professores como intelectuais: rumo a uma pedagogia crítica da aprendizagem. Porto Alegre: Artes Médicas, 1997.

GREGOLIN, M. do R. Foucault e Pêcheux na Análise de Discurso: Diálogos \& Duelos, 2. ed. São Carlos: Claraluz, 2006.

LACAN, J. Escritos. Rio de Janeiro: Jorge Zahar, 1998.

LIMA, M. S. L. Reflexões sobre o estágio/prática de ensino na formação de professores. Revista Diálogo Educacional, Curitiba, v. 8, n. 23, p. 195-205, jan./abr. 2008.

MALDIDIER, D. A inquietude do discurso. Um trajeto na história da Análise do Discurso: o trabalho de Michel Pêcheux. In: PIOVEZANI, C.; SARGENTINI, V. (Orgs.). Legados de Michel Pêcheux. Inéditos em análise do discurso. São Paulo: Editora Contexto, 2011, p. 39-62.

. A Inquietação do discurso. (Re)ler Michel Pêcheux hoje. Campinas: Pontes, 2003. 
ORLANDI, E. P. A linguagem e seu funcionamento - as formas do discurso. São Paulo: Pontes, 2003.

. Análise do discurso: princípios e procedimentos. Campinas, SP: Pontes, 2009. . As formas do silêncio: no movimento dos sentidos, 6. ed. Campinas: Editora da Unicamp, 2007.

PÊCHEUX, M. Semântica e discurso: uma crítica à afirmação do óbvio, 3. ed. Campinas, SP: UNICAMP, 1997.

PIMENTA, S. G.; GHEDIN, E. (Orgs.). Professor reflexivo no Brasil: gênese e crítica de um conceito, 4. ed. São Paulo: Cortez, 2006.

TARDIF, M. Saberes docentes e formação profissional, 13. ed. Petrópolis, RJ: Vozes, 2012.

TFOUNI, L. V. Letramento e alfabetização, 2. ed. São Paulo: Cortez, 1997.

\section{Dados dos Autores:}

Filomena Elaine Paiva Assolini

Doutora da Faculdade de Filosofia, Ciências e Letras de Ribeirão Preto da Universidade de São Paulo. Estudos e pesquisas concentram-se na interface Linguística-Educação Escolar. Especificamente, didedicação aos estudos sobre alfabetização, leitura, letramento e formação de professores. Professora na graduação e na Pós-Graduação em Educação.

\section{Andrea Coelho Lastória}

Faculdade de Filosofia, Ciências e Letras de Ribeirão Preto - FFCLRP - Universidade de São Paulo. Professora do Programa de Pós-Graduação em Educação e do curso de Pedagogia da Faculdade de Filosofia, Ciências e Letras de Ribeirão Preto - FFCLRP, na UNIVERSIDADE DE SÃO PAULO. Licenciada em Geografia e Pedagogia, Bacharel em Geografia, com Mestrado em Doutorado em Educação pela Universidade Federal de São Carlos UFSCar. Coordenadora do Grupo de Estudos da Localidade - ELO. lastoria@ffclrp.usp.br

\section{Erica Mancuso Schaden}

Doutoranda em Educação pela Unicamp (2017), mestre em Educação pela USP (2015), graduada em Pedagogia pela USP (2012) e graduada em Ciências Sociais pela UNICAMP (2008). Especialista em Literatura infantil e contação de histórias na escola pela UNIARA (2016) e Sociologia da Infância pela UFSCar (2016). Tem experiência na área de Educação. Integra o Grupo de Pesquisa ALLE-AULA-UNICAMP. Integrou o Grupos de Estudos e Pesquisas GEPALLE-USP. É professora do Ensino Básico Público. ericamancs@gmail.com

Submissão em: 19/01/2017

Aceito em: 18/02/2018 